\title{
Exploring the Informal Communication of Driver-to-Driver on Roads: A Case Study of Durban City, South Africa
}

\author{
Jacob Adedayo Adedeji ${ }^{*}$, Xoliswa E. Feikie ${ }^{b}$ \\ a Department of Civil Engineering Midlands, Durban University of Technology, Durban, 3021, Republic of South Africa \\ ${ }^{b}$ Department of Civil Engineering and Geomatics, Durban University of Technology, Durban, 4000, Republic of South Africa
}

\begin{tabular}{l} 
A R T I C L E I N F O \\
\hline DOI: 10.31075/PIS.67.04.01 \\
Professional paper \\
Received: $16 / 10 / 2021$ \\
Accepted:13/11/2021 \\
Corresponding author: \\
jacoba@dut.ac.za \\
xoliswaf@dut.ac.za \\
\hline Keywords: \\
Traffic fatalities \\
Informal Communication \\
Road user behaviour \\
Traffic safety \\
Implicit learning
\end{tabular}

\begin{abstract}
A B S TR A C T
Road traffic fatality is rated as one of the ten causes of death in the world and with preventative measures on the global level to reduce traffic fatality, the traffic fatality rate remains high. Nevertheless, the communication by road users is an essential key to traffic safety. This communication, be it formal or informal, is a crucial factor for smooth traffic flow and safety. Communication language on roads can be categorised into; formal device-based signal (formal signal), formal hand signal (formal signal), informal device-based signal (informal signal), and informal gesture-based signal (everyday signal). However, if the intent of the message conveyed is not properly understood by the other road user, mistakes and errors may set in. Overall, the formal signal is based on explicit learning which occurs during the driving training and the license testing process, and the informal, implicit learning occurs during the actual driving process on the road unintentionally. Furthermore, since the informal signal is not a prerequisite to driving or taught in driving schools, novice drivers are oblivious and thus, might contribute to errors and mistakes that lead to traffic fatalities. This paper seeks to document the informal means of communication between drivers on South African roads. A quantitative semi-structured interview questionnaire was used in the collection of informal communication, which were predominantly used on South African roads by different drivers. Results of the study show that informal communication exists and is learnt based on an implicit mode of learning, and this paper proposed possible adaption of the informal communication to the K53 learner's and driver's manual.
\end{abstract}

\section{Introduction}

Road traffic injuries are the leading cause of death for children and young adults aged 5-29 years and traffic fatality is rated as one of the ten causes of death in the world (Zhang et al., 2013; World Health Organization (WHO), 2015). Various measures have been put in place to combat traffic fatality such as rehabilitation of poor roads, improvement and availability of traffic communication tools; traffic signs, road marking, and traffic signals, and implementation of new traffic rules and regulations (Adedeji et al., 2016; Adedeji et al., 2018; Adedeji et al., 2021). Despite all the various preventative measures on the global level to reduce traffic fatality, the traffic fatality rate remains high. Additionally, traffic fatality has been blamed on road factors such as poor road condition, poor maintenance, poor geometric design, absence of traffic signs and signal.
Other factors such as drunk driving, over speeding, violation of traffic rules, distraction and poor communication between drivers have also been attributed to traffic fatality (Bun, 2012; Agbonkhese et al., 2013; Adedeji et al., 2016). In addition, traffic fatality is still too high, for example, in the case of South Africa, traffic fatality statistic for 2019 was sitting at 12503 only declining by 3.2 percent when compared to 12921 in 2018 (Road Traffic Management Corporation, 2020).

Overall, the behaviour of road users is essential to traffic safety, since the human factor is one of the major contributors to traffic fatalities (Hung, 2011; Chen and Jou, 2019). Nevertheless, drivers' characteristics in terms of visual activity and reaction process are of significant importance, in addition to this is the interaction between drivers. 
Drivers are equipped with communication skills through the learner's and driver's license training and testing process. Communication could be formal or informal. Communication language on roads can be categorised into; formal device-based signal (formal signal), formal hand signal (formal signal), informal device-based signal (informal signal), and informal gesture-based signal (everyday signal) (Renge, 2000; Björklund and Âberg, 2005). If the intent of the message conveyed is not properly understood by the other road users, mistakes and errors may set in. Generally, the formal signal is based on explicit learning which occurs during the driving training and the license testing process, and the informal, implicit learning occur during the actual driving process on the road unintentionally.

\subsection{Explicit Learning in Driving}

According to Dornyei (2009), explicit learning refers "to the learner's conscious and deliberate attempt to master some material or solve a problem" and this typically involves memorising a series of successive facts. Thus, heavy demands on working memory take place consciously and result in symbolic knowledge (Ellis, 2009). Learners' and driving license testing is explicit as these tests explore conscious and deliberate attempts to master driving skills and the use of formal signals. Learners' and drivers' license testing process involves learning about controls of the vehicle, road signs and rules of the road (Hoole, 2013; Habibovic et al., 2018), and thereafter learner's and drivers' driving skill will be tested. This concept agrees with the selective learning component of explicit learning (Figure 1) (Levin and Buccafusco, 2006). In addition, the driving instructor trains the learner driver on the interaction with other road users using the formal language (controls of the vehicle, road signs, and rules of the road) and during the testing process, drivers are expected to recall information with conscious effort. However, informal communication is not taught during the process and the driver relies on experience to understand them.

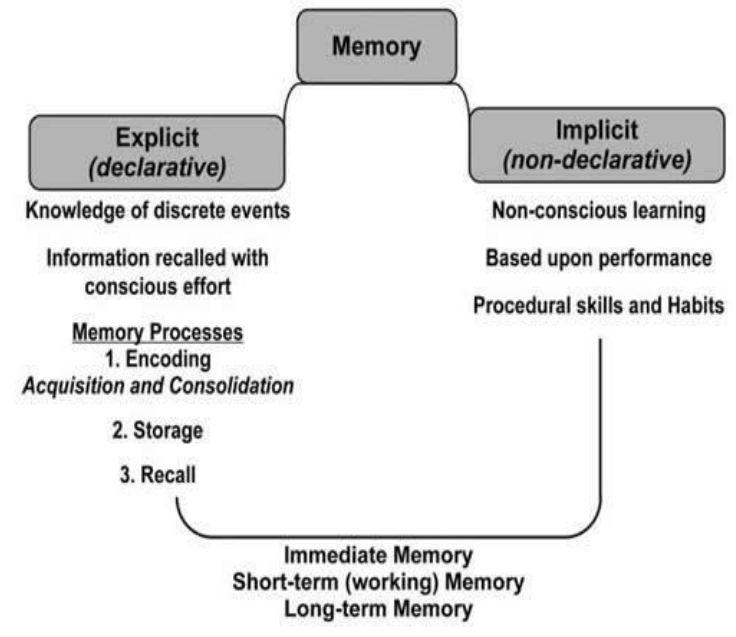

Figure 1. Explicit and implicit learning and memory Source: Levin and Buccafusco, 2006

\subsection{Implicit Learning in Driving}

In contrast, implicit learning involves acquiring skills and knowledge without conscious awareness, that is, automatically and with no conscious attempt to learn them (Figure 1) (Dornyei, 2009). Implicit learning happens without a guide, especially in an informal setups and language (Williams et al., 2004; Ellis, 2009; Habibovic et al., 2018). Implicit learning in driving occurs after the learner's and driver's license testing process, the driver continues to learn, based on the driving environment and the interaction between the drivers or other road users. Implicit learning is a nonselective learning mode, that is in the case of driving, the driver is not instructed on the situation, but the driver learns in the course of driving. Furthermore, since informal communication is not a prerequisite to driving, and it is not taught in driving schools, novice drivers are oblivious to the language and thus, might contribute to errors that may lead to traffic fatalities. Nonetheless, communication is an essential key to traffic safety. This communication, be it formal or informal between the road users is a key factor for smooth traffic flow and safety. This study seeks to explore and document the informal communication between drivers on South African roads. The remaining part of the paper includes sections on the study approach, data analysis, finding from the study and overall discussion and conclusion on the current study.

\section{Approach of Study}

The study area is Durban, which is the largest coastal city in the KwaZulu-Natal province and the most populous urban area in South Africa after Johannesburg and Cape Town. In the first quarter of the year 2020, KwaZulu-Natal province records an increase in road fatalities (ENCA, 2021). While there was an overall decrease of $10 \%$ in road fatalities in South Africa for the year 2020, the KwaZulu-Natal province recorded only a $5 \%$ decline. Compare to other provinces, this was the least decline, excluding Limpopo \& Gauteng which experienced an increase (Transport Ministry Republic of South Africa, 2020).

Quantitative semi-structured interviews questionnaire method was used to collect data from the driving instructors and drivers in Durban, KwaZulu-Natal. The questionnaire was uploaded on the QuestionPro online platform, and the link was sent to different driving schools in Durban and individual drivers on a random basis.

One hundred and three respondents were interviewed, and recorded questionnaires were returned in total. The questionnaire used consists of three sections, the first section deals with demographic characteristics of respondents such as age, gender, and category of road user. 
The second section deals with the driving experiences concerning informal communication. The third section deals with the validation and their understanding of this informal communication.

\subsection{Data Analysis}

Data was analysed using the QuestionPro analysis package and SPSS. Standard descriptive statistics were reported in frequency count (\%) for categorical variables. In addition, a cross-tabulation with chisquare analysis was conducted to establish the relationship between the driver's characteristics and informal communication. The null and alternative hypotheses for the testing were:

$\mathrm{H}_{0}$ : The driver's characteristics and their view of informal communication are independent of each other.

\section{$\mathrm{H}_{\mathrm{i}}$ : Null hypothesis is not true}

The expected cell frequencies were compared with the observed cell frequencies using the test chi-square, as estimated.

$$
X^{2}=\sum \frac{\left(O_{i}-E_{j}\right)^{2}}{E_{i j}}
$$

where:

$X^{2}=$ chi-square

$O_{i j}=$ observed frequency of the cell in the $i$ th row and $j$ th column

$E_{i j}=$ expected frequency of the cell in the $i$ th row and $j$ th column

The calculated chi-square result was compared with the critical chi-square value (using the table) with $(r-1)$ $x(c-1)$ degree of freedom to decide on the acceptance or rejection of the null hypothesis (Pandis, 2016). Overall, decision rule is based on; If $X^{2}$ tab $>X^{2}$ cal, accept $\mathrm{H}_{\mathrm{o}}$, otherwise reject.

\subsection{Respondents}

Most respondents of the study were male $(68 \%$ ) (Table 1 ). Only $4 \%$ of the respondents were above 50 years of age, and most of the respondents (83\%) were under the age of 40 years. The study focused on different drivers where $75 \%$ were private drivers, $11 \%$ driving were instructors; and $32 \%$ were commercial drivers. The commercial drivers include hailing app drivers (21\%), taxi/minibus drivers (24\%), bus drivers $(26 \%)$, and truck drivers (29\%). The majority (42\%) of instructors had experience of above 5 years (Table 1). The study considered the different types of drivers to get different perspectives of the importance of driverto-driver communication on the roads.
Table 1. Demographic Data $(\mathrm{N}=103)$

\begin{tabular}{|c|c|}
\hline Item & Percent \\
\hline Male & 68 \\
\hline Female & 32 \\
\hline Age & 19 \\
\hline $18-25$ & 31 \\
\hline $26-30$ & 33 \\
\hline $31-39$ & 13 \\
\hline $40-49$ & 4 \\
\hline Above 50 & 11 \\
\hline Type of driver & 32 \\
\hline Driving Instructor & 75 \\
\hline Commercial Driver & \\
\hline Private Driver & 24 \\
\hline If Commercial (Which) & 21 \\
\hline Taxi/Minibus & 26 \\
\hline App Hailing & 29 \\
\hline Bus Driver & \\
\hline Truck Driver & 17 \\
\hline If instructor years & 33 \\
\hline $0-2$ & 42 \\
\hline 3-5 & 8 \\
\hline 6-10 & \\
\hline Over 10 & \\
\hline
\end{tabular}

Source: Adedeji and Feikie, 2021.

\section{Findings of Study}

Another section of the study was aimed at investigating if different drivers are aware of informal communication between drivers and its importance. The study revealed that $95 \%$ of the drivers are aware and they understand informal communication used by drivers on South African roads (Table 2). Additionally, $63 \%$ of the respondents indicated that they have not been instructed about informal communication, while $37 \%$ indicated the opposite. When asked about the need to teach informal communication to new drivers, $53 \%$ of the respondents rated initiative 5 (very necessary), while $37 \%$ rated it between 2-4 (fairly necessary - necessary), and $11 \%$ said it is not necessary (Table 2).

When asked about the importance of informal communication, $57 \%$ of the respondents rated the initiative 5 (very important), while $38 \%$ rated it $2-4$ (fairly important to important), and $5 \%$ said it is not important (Table 2). Also, from Table 2, 52\% strongly agreed, $18 \%$ agreed, $14 \%$ neutral and $16 \%$ disagreed that lack of understanding of informal communication can lead to traffic fatalities. These findings show that drivers are aware of informal communication between drivers, and they use them while driving. Other drivers indicate this type of communication as important, and they indicate that a lack of their understanding may contribute to traffic fatalities. 
Table 2. Driver to Driver Communication

\begin{tabular}{|c|c|c|}
\hline $\begin{array}{l}\text { Driver to Driver } \\
\text { Communication }\end{array}$ & Class & Percentage (\%) \\
\hline \multirow{2}{*}{$\begin{array}{l}\text { Do you understand } \\
\text { driver to driver } \\
\text { communication? }\end{array}$} & Yes & 95 \\
\hline & No & 5 \\
\hline \multirow{2}{*}{$\begin{array}{l}\text { Are you aware of } \\
\text { informal } \\
\text { communication } \\
\text { used on South } \\
\text { African Roads? }\end{array}$} & Yes & 95 \\
\hline & No & 5 \\
\hline \multirow{2}{*}{$\begin{array}{l}\text { Do you instruct/ } \\
\text { have been } \\
\text { instructed about } \\
\text { informal } \\
\text { communication } \\
\text { between drivers? }\end{array}$} & Yes & 37 \\
\hline & No & 63 \\
\hline \multirow{5}{*}{$\begin{array}{l}\text { Do you think } \\
\text { learners should be } \\
\text { taught informal } \\
\text { communication? }\end{array}$} & Not Necessary (1) & 11 \\
\hline & $\begin{array}{l}\text { Fairly Necessary } \\
\text { (2) }\end{array}$ & 5 \\
\hline & Neutral (3) & 17 \\
\hline & Necessary (4) & 15 \\
\hline & $\begin{array}{l}\text { Very Necessary } \\
\text { (5) }\end{array}$ & 52 \\
\hline \multirow{5}{*}{$\begin{array}{l}\text { How important is } \\
\text { informal } \\
\text { communication? }\end{array}$} & Not Important (1) & 5 \\
\hline & $\begin{array}{l}\text { Fairly Important } \\
\text { (2) }\end{array}$ & 1 \\
\hline & Neutral (3) & 10 \\
\hline & Important (4) & 27 \\
\hline & Very Important (5) & 57 \\
\hline \multirow{5}{*}{$\begin{array}{l}\text { Do you think that } \\
\text { lack of } \\
\text { understanding of } \\
\text { informal } \\
\text { communication can } \\
\text { contribute to traffic } \\
\text { fatalities? }\end{array}$} & $\begin{array}{c}\text { Strongly Disagree } \\
\text { (1) }\end{array}$ & 8 \\
\hline & Disagree (2) & 8 \\
\hline & Neutral (3) & 14 \\
\hline & Agree (4) & 18 \\
\hline & Strongly Agree (5) & 52 \\
\hline
\end{tabular}

Source: Adedeji and Feikie, 2021

\subsection{Informal Signal on South Africa Road}

\subsubsection{Cross-Classification Respondent Class and The Need to Teach Learners Informal Communication}

Table 3, as presented below shows a crossclassification analysis of respondent class and the need to teach learner drivers informal communication. Considering a $5 \%$ level of significance, the chi-square value is 17.95. The calculated chi-square values for the need to teach learner drivers were larger than the critical value (15.507), thus, indicating that the different drivers and their opinion on the need to teach learners informal communication are dependent on each other. This implies that different driver classes (driving instructor, commercial and private drivers) can influence their agreement about teaching informal communication.
Table 3. Do you think learners should be taught informal communication? * Respondent Class

\begin{tabular}{|c|c|c|c|c|c|}
\hline \multirow[b]{2}{*}{$\begin{array}{l}\text { Respondent } \\
\text { Class }\end{array}$} & \multicolumn{5}{|c|}{$\begin{array}{l}\text { Do you think learners should be taught } \\
\text { informal communication? }\end{array}$} \\
\hline & $\begin{array}{c}\text { Not } \\
\text { Nec } \\
\text { essa } \\
\text { ry }\end{array}$ & $\begin{array}{c}\text { Fairly } \\
\text { Necess } \\
\text { ary }\end{array}$ & $\begin{array}{l}\text { Neutr } \\
\text { al }\end{array}$ & $\begin{array}{c}\text { Necess } \\
\text { ary }\end{array}$ & $\begin{array}{c}\text { Very } \\
\text { Necessa } \\
\text { ry }\end{array}$ \\
\hline $\begin{array}{l}\text { Driving } \\
\text { Instructor }\end{array}$ & 27 & 0 & 24 & 0 & 10 \\
\hline $\begin{array}{c}\text { Commercial } \\
\text { Driver }\end{array}$ & 9 & 20 & 18 & 20 & 47 \\
\hline $\begin{array}{l}\text { Private } \\
\text { Drivers } \\
\end{array}$ & 64 & 80 & 58 & 80 & 43 \\
\hline $\begin{array}{l}\text { Chi-square } \\
\text { Test Statistic }\end{array}$ & \multicolumn{5}{|c|}{17.95} \\
\hline $\mathrm{H}_{\mathrm{o}}$ Rejected? & \multicolumn{5}{|c|}{ Yes } \\
\hline
\end{tabular}

Source: Adedeji and Feikie, 2021.

\subsubsection{Cross-Classification Respondent Class and The Importance of Informal Communication Between Drivers}

Table 4, as presented below, shows a crossclassification analysis of the respondent class and the importance of informal communication between drivers. Considering a $5 \%$ level of significance, the chisquare value is 19.69. The calculated chi-square values were larger than the critical value (15.507), thus indicating there is a significant relationship between the drivers' class and the importance of informal communication. Results show that different driver classes influence their agreement about the importance of informal communication.

Table 4. How important is informal communication? * Respondent Class

\begin{tabular}{|c|c|c|c|c|c|}
\hline \multirow{2}{*}{$\begin{array}{c}\text { Respondent } \\
\text { Class }\end{array}$} & \multicolumn{4}{|c|}{ How important is informal communication? } \\
\cline { 2 - 6 } & $\begin{array}{c}\text { Not } \\
\text { Impor } \\
\text { tant }\end{array}$ & $\begin{array}{c}\text { Fairly } \\
\text { importa } \\
\text { nt }\end{array}$ & $\begin{array}{c}\text { Neutr } \\
\text { al }\end{array}$ & Important & $\begin{array}{c}\text { Very } \\
\text { importa } \\
\text { nt }\end{array}$ \\
\hline $\begin{array}{c}\text { Driving } \\
\text { Instructor }\end{array}$ & 40 & 0 & 20 & 0 & 14 \\
\hline $\begin{array}{c}\text { Commercial } \\
\text { Driver }\end{array}$ & 0 & 0 & 0 & 29 & 44 \\
\hline $\begin{array}{c}\text { Private } \\
\text { Drivers }\end{array}$ & 60 & 100 & 80 & 71 & 42 \\
\hline $\begin{array}{c}\text { Chi-square } \\
\text { Test Statistic }\end{array}$ & \multicolumn{5}{|c|}{19.69} \\
\hline Ho Rejected? & \multicolumn{7}{|c|}{ Yes } \\
\hline
\end{tabular}

Source: Adedeji and Feikie, 2021.

\subsubsection{Cross-Classification Respondent Class and The Contribution of Lack of Understanding of Informal Communication to Traffic Fatalities}

Table 5 presents the cross-classification analysis of respondent class and the contribution of lack of understanding of informal communication to traffic fatalities. Considering a $5 \%$ level of significance, the chi-square value is 3.92 . 
The calculated chi-square values were less than the critical value (15.507), thus, indicating that there is no significant relationship between the variables. This implies that different driver classes do not influence their agreement about the contribution of traffic fatalities because of lack of understanding of informal communication.

Table 5. Do you think that lack of understanding of informal communication can contribute to traffic fatalities? * Respondent Class

\begin{tabular}{|c|c|c|c|c|c|}
\hline \multirow{2}{*}{$\begin{array}{c}\text { Respondent } \\
\text { Class }\end{array}$} & \multicolumn{5}{|c|}{$\begin{array}{c}\text { Do you think that lack of understanding of } \\
\text { informal communication can contribute to traffic } \\
\text { fatalities? }\end{array}$} \\
\cline { 2 - 6 } & $\begin{array}{c}\text { Strongly } \\
\text { Disagree }\end{array}$ & Disagree & Neutral & Agree & $\begin{array}{c}\text { Strongly } \\
\text { Agree }\end{array}$ \\
\hline $\begin{array}{c}\text { Driving } \\
\text { Instructor }\end{array}$ & 25 & 13 & 7 & 11 & 12 \\
\hline $\begin{array}{c}\text { Commercial } \\
\text { Driver }\end{array}$ & 25 & 25 & 29 & 22 & 38 \\
\hline $\begin{array}{c}\text { Private } \\
\text { Drivers }\end{array}$ & 50 & 62 & 64 & 67 & 50 \\
\hline $\begin{array}{c}\text { Chi-square } \\
\text { Test Statistic }\end{array}$ & \multicolumn{5}{|c|}{3.92} \\
\hline$H_{0}$ Rejected?
\end{tabular}

Source: Adedeji and Feikie, 2021.

The findings indicate that different drivers have different perspectives when it comes to informal communication. Even though the results in Table 2 show that most of the respondents agree that: 1) that learner drivers need to be taught informal communication; 2) informal communication is important on roads; and 3) the lack of understanding of informal communication can contribute to traffic fatalities. The results from Tables 3 and 4 show that the importance or lack thereof is dependent on the type of driver, while the results from Table 5, show that where the contribution of lack of understanding of informal communication to traffic fatalities is concerned, there is no significant relationship on the type of driver.

\subsection{Available Informal Communication}

Table 6 below shows the results of the cross-tabulation between respondent class and informal signals. This analysis highlighted the availability and understanding of informal signals or communication between drivers. The results indicate that most drivers have a common understanding of informal communication or signals, except for "Indicate to tell the driver, it's safe to overtake" and "Flashlights to tell the other driver to dim their lights", where the majority of respondents indicated that they are not aware of the interpretation.
Table 6. Available informal communication on South African roads

\begin{tabular}{|c|c|c|c|}
\hline \multirow{2}{*}{ Informal Signals } & \multirow{2}{*}{ Respondent Class } & \multicolumn{2}{|c|}{ Percentage } \\
\hline & & Yes & No \\
\hline \multirow{3}{*}{$\begin{array}{l}\text { Flashing front light } \\
\text { to ask the driver in } \\
\text { the front to move } \\
\text { from the fast lane }\end{array}$} & Driving Instructor & 7 & 17 \\
\hline & Commercial Driver & 13 & 57 \\
\hline & Private Driver & 80 & 26 \\
\hline \multicolumn{2}{|c|}{ Total percentage } & 54 & 46 \\
\hline \multirow{3}{*}{$\begin{array}{l}\text { Flashing front lights } \\
\text { to greet the driver }\end{array}$} & Driving Instructor & 12 & 11 \\
\hline & Commercial Driver & 14 & 57 \\
\hline & Private Driver & 74 & 32 \\
\hline \multicolumn{2}{|c|}{ Total percentage } & 56 & 44 \\
\hline \multirow{3}{*}{$\begin{array}{l}\text { Flashing front } \\
\text { lights/Hoot to } \\
\text { indicate danger }\end{array}$} & Driving Instructor & 9 & 17 \\
\hline & Commercial Driver & 28 & 45 \\
\hline & Private Driver & 63 & 38 \\
\hline \multicolumn{2}{|c|}{ Total percentage } & 71 & 29 \\
\hline \multirow{3}{*}{$\begin{array}{c}\text { Using hazards to } \\
\text { indicate that the car } \\
\text { is stopping/slowing } \\
\text { down }\end{array}$} & Driving Instructor & 6 & 23 \\
\hline & Commercial Driver & 25 & 49 \\
\hline & Private Driver & 69 & 29 \\
\hline \multicolumn{2}{|c|}{ Total percentage } & 65 & 35 \\
\hline \multirow{3}{*}{$\begin{array}{l}\text { Using hazards to say } \\
\text { "Thank you" after } \\
\text { overtaking }\end{array}$} & Driving Instructor & 10 & 15 \\
\hline & Commercial Driver & 15 & 62 \\
\hline & Private Driver & 75 & 23 \\
\hline \multicolumn{2}{|c|}{ Total percentage } & 61 & 39 \\
\hline \multirow{3}{*}{$\begin{array}{l}\text { Indicate to tell the } \\
\text { driver, it's safe to } \\
\text { overtake }\end{array}$} & Driving Instructor & 4 & 17 \\
\hline & Commercial Driver & 9 & 54 \\
\hline & Private Driver & 87 & 30 \\
\hline \multicolumn{2}{|c|}{ Total percentage } & 46 & 54 \\
\hline \multirow{3}{*}{$\begin{array}{l}\text { Indicate to tell the } \\
\text { driver to join traffic }\end{array}$} & Driving Instructor & 12 & 13 \\
\hline & Commercial Driver & 16 & 69 \\
\hline & Private Driver & 72 & 19 \\
\hline \multicolumn{2}{|c|}{ Total percentage } & 68 & 32 \\
\hline \multirow{3}{*}{$\begin{array}{l}\text { Flash lights to tell } \\
\text { the other driver to } \\
\text { dim their lights }\end{array}$} & Driving Instructor & 0 & 28 \\
\hline & Commercial Driver & 50 & 42 \\
\hline & Private Driver & 50 & 31 \\
\hline \multicolumn{2}{|c|}{ Total percentage } & 10 & 90 \\
\hline
\end{tabular}

Source: Adedeji and Feikie, 2021.

\subsection{Classification of Available and Interpretation of Informal Communication}

Table 7 is adopted from the findings of Table 6. Six (6) static visual scenarios (Figure 2-7) are created using the Paint 3D (C) (Microsoft, 2016) application software and presented in Table 7 in terms of action, interpretation, and reaction. The six scenarios represent the basic possible evidence of informal communication on South African roads. The informal communication type was classified based on the various road signs classification such as warning, regulatory, guidance and information (Hoole, 2013). Warning class alter drivers of impending danger ahead; regulatory class enforces the drivers in making a decision; guidance class provide a guide to the driver on decisions and information class provides drivers with a causal compliment or suggest decision that can be taken by the drivers. Just as road signs are typically placed in advance of an upcoming hazard to initiate a change in driver behaviour, so is informal communication. Overall, the communication should be uniform to minimise confusion and uncertainty about their meaning especially for novice drivers, as a misunderstanding of communication can contribute to traffic accidents. 


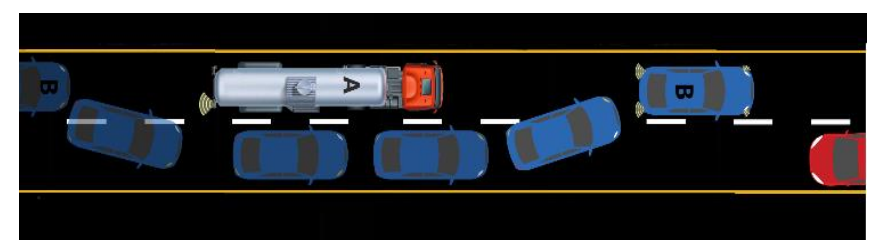

Figure 2. Scenario 1: Indicate to tell the driver that it's safe to overtake Source: Adedeji and Feikie, 2021.

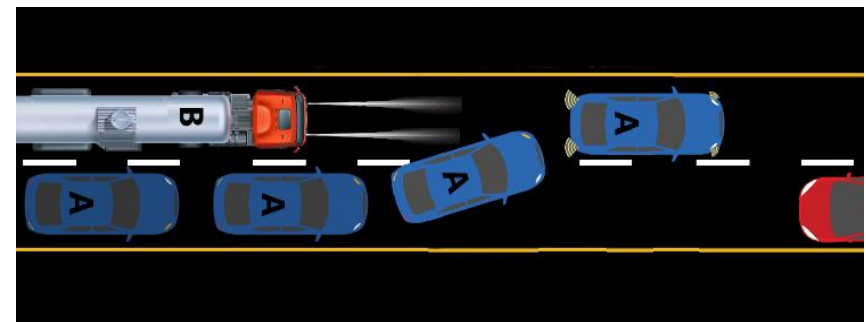

Figure 3. Scenario 2: Car A: Using hazards to say "Thank you" after overtaking; Truck B: Flashing front lights to greet the driver Source: Adedeji and Feikie, 2021.

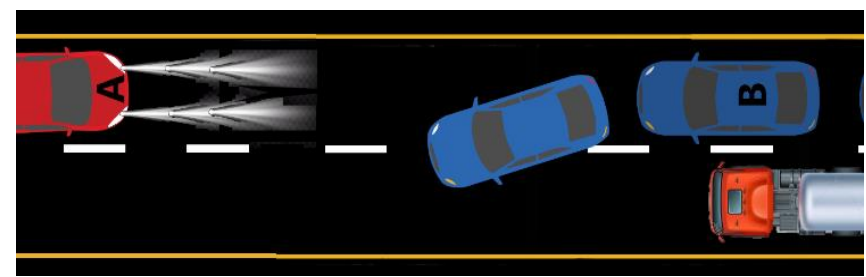

Figure 4. Scenario 3: Car A continuous flick full beam, give way Source: Adedeji and Feikie, 2021.

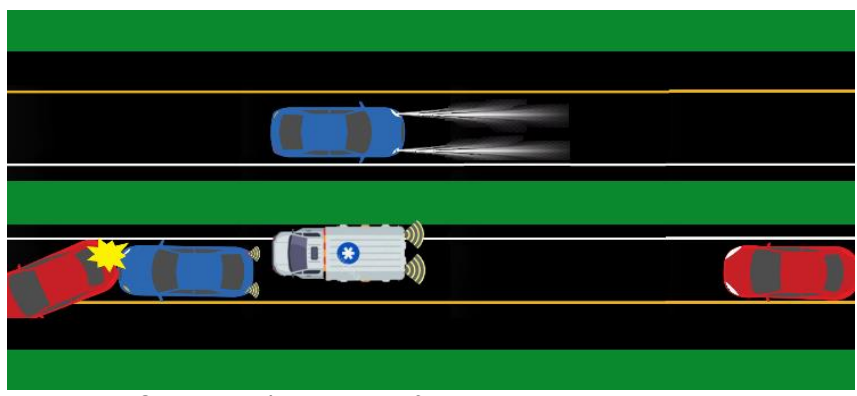

Figure 5. Scenario 4: Flashing front lights/Hoot to indicate danger Source: Adedeji and Feikie, 2021.

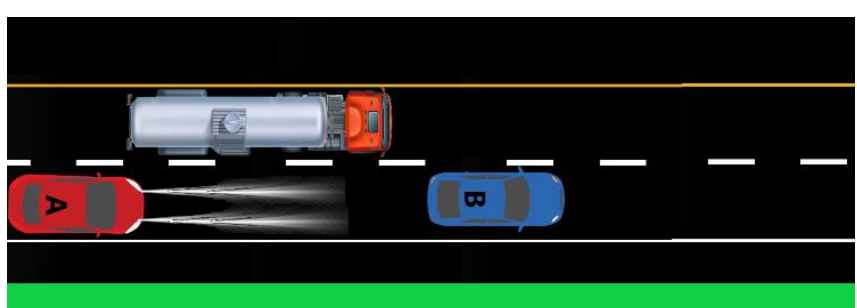

Figure 6. Scenario 5: Flash to move out of the fast lane Source: Adedeji and Feikie, 2021.

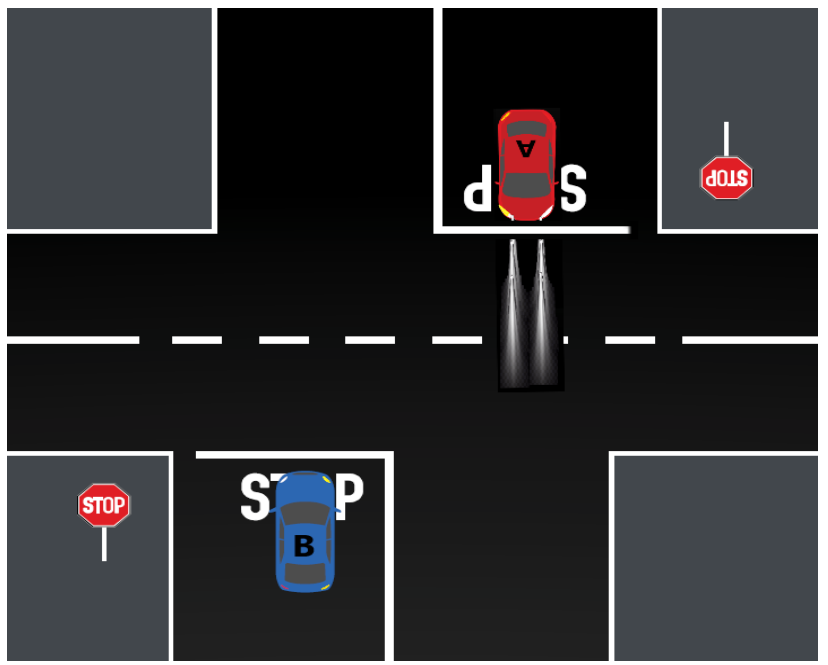

Figure 7. Scenario 6: Flash the lights to permit to enter traffic. Source: Adedeji and Feikie, 2021.

Table 7. Classification of informal communication

\begin{tabular}{|c|c|c|c|c|c|}
\hline Scenarios & Action & Interpretation & Reaction & Classification & Ref. Figure \\
\hline \multirow{2}{*}{1} & $\begin{array}{l}\text { Truck A continuously } \\
\text { indicate to the right }\end{array}$ & $\begin{array}{c}\text { Flick to tell the driver } \\
\text { behind to pass /overtake }\end{array}$ & Car B quickly overtaking truck $\mathbf{A}$ & Guidance & 2 \\
\hline & $\begin{array}{l}\text { Car B after overtaking turns } \\
\text { on the hazard light twice }\end{array}$ & Hazards to say thank you & $\begin{array}{l}\text { Truck A response with a single beam } \\
\text { flash }\end{array}$ & Information & 2 \\
\hline 2 & $\begin{array}{l}\text { Truck } \mathbf{A} \text { response with a } \\
\text { single beam flash }\end{array}$ & You are welcome & - & Information & 3 \\
\hline 3 & $\begin{array}{l}\text { Car A continually flick full } \\
\text { beam }\end{array}$ & $\begin{array}{l}\text { Flash to move out of the } \\
\text { way }\end{array}$ & $\begin{array}{c}\text { Car B quickly completes the overtaking } \\
\text { or withdraw if the overtaking sight } \\
\text { distance is too small }\end{array}$ & Regulatory & 4 \\
\hline 4 & $\begin{array}{c}\text { The continuous flick of a full } \\
\text { beam from the other lane }\end{array}$ & $\begin{array}{c}\text { Flashing light to indicate } \\
\text { danger ahead }\end{array}$ & $\begin{array}{c}\text { Car on the other lane responses with a } \\
\text { single full beam }\end{array}$ & Warning & 5 \\
\hline 5 & $\begin{array}{l}\text { Car A continually flick full } \\
\text { beam }\end{array}$ & $\begin{array}{l}\text { Flash to move out of the } \\
\text { fast lane }\end{array}$ & Car $\mathbf{B}$ moves out of the fast lane & Regulatory & 6 \\
\hline 6 & $\begin{array}{c}\text { Car } \mathbf{A} \text { and Car } \mathbf{B} \text { arrive at } \\
\text { the stop sign at the same } \\
\text { time. } \\
\text { Car } \mathbf{A} \text { flick full-beam max } \\
\text { three times }\end{array}$ & $\begin{array}{l}\text { Flash the lights to give } \\
\text { permission to enter traffic }\end{array}$ & Car $\mathbf{B}$ makes the first move to turn right & Guidance & 7 \\
\hline
\end{tabular}

Source: Adedeji and Feikie, 2021 


\section{Discussion}

Overall, the findings from the study show that informal communication exists and is learnt based on an implicit mode of learning. The findings are of direct practical relevance in terms of the South African context and the rest of the world. Firstly, informal communication can be considered for adaptation into the K53 learner's and driver's manuals, as this can be beneficial to both experienced and learner drivers. Secondly, informal communication can be adapted into the interaction between automated vehicles and pedestrians, and human-driving vehicles. Finally, the programming of the informal communication for the automated vehicle using the concept of machine learning language.

\subsection{Adaptation of Informal Communication to K53}

The K53 learner's and driver's manuals are comprehensive and effective guides for preparing the learners and drivers for their licencing test in South Africa. The manual covers detail around light and heavy motor vehicles and motorcycles (Hoole, 2013).

K53 manual covers defensive driving principles, roads and other rules for the learners and details with regards to a step-by-step guide for the drivers. Overall, the manual provides explicit guidelines in operating in and around the roadways in terms of formal communication. However, contains little to none on the informal communication, the implicit guidelines. Based on the current findings of the study, informal communication is not taught to learners and respondents agree that they should be taught and be officially used on the road. Hence, the study suggests that informal communication should be standardised and adapted into the K53 manual.

\subsection{Interactions between Autonomous Vehicles and Pedestrians}

The interaction between conventional vehicles and pedestrians is complex and still not fully understood, as various factors are contributing to the complexity of the situation (Habibovic et al., 2018). Pedestrians often rely on non-verbal cues from drivers such as eye contact, postures, gesture, or even informal communication. However, with the advent of autonomous vehicles, the aforementioned, apart from informal communication, will be off the table. Research has shown that autonomous vehicles should be equipped with clear information for pedestrians about their mode and intent (Malmsten Lundgren et al., 2017; Habibovic et al., 2018). Due to the vagueness of nonverbal communication which the pedestrians are used to, this study suggests exploring informal communication as vehicle design solutions to communicate with pedestrians.

\subsection{Interaction between Autonomous and Human- Driving Vehicles}

Transitions between human and automated driving is a key design issue for autonomous vehicles. However, it is critical that autonomous vehicles can communicate not only with other autonomous vehicles but also with human-driving vehicles (Jafary et al., 2018). This interaction between autonomous vehicles and humandriving vehicles is complex because of the human element present. Conventional drivers in humandriving vehicles are used to using formal and informal communication means to communicate with other drivers as shown in this study. Autonomous vehicles, also use formal communication, however, still need informal communication to interact with human-driving vehicles. Hence, the need to program autonomous vehicles with informal communication as highlighted in this study is a necessity.

\section{Conclusion}

The main aim of the paper was to explore and document the informal means of communication between drivers on South African roads. The study shows that.

- Informal communications exist on South African roads and the drivers and driving instructors are aware of their availability.

- The majority of the drivers have not been instructed about informal communication, yet they know about them based on the implicit mode of learning.

- Informal communication is very important, and respondents somewhat agree that lack of understanding of this communication means could contribute to traffic fatalities.

Furthermore, the study shows that there was a significant association between drivers' views and teaching learner drivers about informal communication and the importance of informal communication. On the contrary, from this study, there is no significant association between drivers' views and lack of understanding of informal communication as a contributor to traffic fatalities.

Further research work will involve the use of traffic simulation tools such as PTV Vissim in developing actual moving visual scenarios and a focus group of pedestrians, passengers' cars, commercial and truck drivers will be used to validate the availability and their understanding of these informal signals using a Likerttype scale for the confidence level. This will be used to assess if the driver-to-driver communication is a contributing factor to traffic accidents. 


\section{References}

[1] Adedeji, J. A., Abejide, S. O., Monts'i, M., Hassan, M. M., \& Mostafa, W. H. (2018). Reaction Behaviour of Drivers to Road Markings: Case Study of Main South Road Lesotho-N8 Road South Africa. In International Congress and Exhibition" Sustainable Civil Infrastructures: Innovative Infrastructure Geotechnology" (pp. 5871). Springer, Cham.

[2] Adedeji, J. A., Abejide, S.O. \& Mostafa Hassan, M. (2016). Effectiveness of Communication Tools in Road Transportation: Nigerian Perspective. In proceedings of the International Conference on Traffic and Transport Engineering ICTTE, Belgrade 2016, pp 510- 517

[3] Adedeji, J.A, Feikie, X., Dzogbewu, T., \& Mostafa, M. (2021). Reaction behaviour of drivers to marked and unmarked road: Ghana perspective. Put I Saobraćaj, 67(1), 1-6. https://doi.org/10.31075/PIS.67.01.01

[4] Adedeji, J.A., \& Feikie, X. (2021). [Informal communication of driver to driver]. Unpublished raw data.

[5] Agbonkhese, O., Yisa, G.L., Agbonkhese, E.G., Akanbi, D.O., Aka, E.O., \& Mondigha, E.B. 2013. Road traffic accidents in Nigeria: causes and preventive measures, Civil and environmental research, 3(13): 90-99.

[6] Björklund, G. M., \& Åberg, L. (2005). Driver behaviour in intersections: Formal and informal traffic rules. Transportation Research Part F: Traffic Psychology and Behaviour, 8(3), 239-253.

[7] Bun, E. 2012. Road Traffic Accidents in Nigeria: A Public Health Problem, AFRIMEDIC Journal, 3(2): 34-36.

[8] Chen, T. Y., \& Jou, R. C. (2019). Using HLM to investigate the relationship between traffic accident risk of private vehicles and public transportation. Transportation Research Part A: Policy and Practice, 119, 148-161.

[9] Dornyei, Z. (2009). The psychology of second language acquisition. Oxford: Oxford University Press.

[10]Ellis, R. (2009). Implicit and explicit learning, knowledge and instruction. Implicit and explicit knowledge in second language learning, testing and teaching, 42, 3-25.

[11]ENCA. (2021). KZN records increase in road fatalities. $\quad$ https://www.enca.com/news/kznrecords-increase-road-fatalitie. [accessed Oct 14 2021].

[12] Habibovic, A., Lundgren, V. M., Andersson, J., Klingegård, M., Lagström, T., Sirkka, A., \& Larsson, P. (2018). Communicating intent of automated vehicles to pedestrians. Frontiers in psychology, 9, 1336.
[13] Hoole, G. (2013). The New Official K53 Manual: Motorcycles, light and heavy vehicles. Penguin Random House South Africa.

[14]Hung, K. V. (2011). Education influence in traffic safety: A case study in Vietnam. IATSS research, 34(2), 87-93.

[15]Jafary, B., Rabiei, E., Diaconeasa, M. A., Masoomi, H., Fiondella, L., \& Mosleh, A. (2018). A survey on autonomous vehicles interactions with human and other vehicles. In 14th PSAM International Conference on Probabilistic Safety Assessment and Management.

[16] Levin, E. D., \& Buccafusco, J. J. (2006). Animal models of cognitive impairment. CRC press.

[17] Malmsten Lundgren, V., Habibovic, A., Andersson, J., Lagström, T., Nilsson, M., Sirkka, A., et al. (2017). "Will there be new communication needs when introducing automated vehicles to the urban context?," in Advances in Human Aspects of Transportation, eds N. A. Stanton, S. Landry, G. Di Bucchianico, and A. Vallicelli (Berlin: Springer International Publishing), 485-497. doi: 10.1016/j.aap.2012.09.023

[18] Microsoft, (2016). Paint 3D. https://www.microsoft.com/en-us/p/paint3d/9nblggh5fv99?activetab=pivot:overviewtab [accessed June 14 2021].

[19] Pandis, N. (2016). The chi-square test. American journal of orthodontics and dentofacial orthopedics, 150(5), 898-899.

[20] Renge, K. (2000). Effect of driving experience on drivers' decoding process of roadway interpersonal communication. Ergonomics, 43(1), 27-39.

[21]Road Traffic Management Corporation. (2020). https://www.rtmc.co.za/ [accessed June 14 2021].

[22] Transport Ministry Republic of South Africa. (2020). https://www.transport.gov.za/ [accessed Oct 14 2021].

[23] Williams, J. N., VanPatten, B., Williams, J., Rott, S., \& Overstreet, M. (2004). Implicit learning of form-meaning connections. Form-meaning connections in second language acquisition, 203218.

[24] World Health Organization. (2015). Global status report on road safety 2015. World Health Organization.

[25]Zhang, G., Yau, K. K., \& Chen, G. (2013). Risk factors associated with traffic violations and accident severity in China. Accident Analysis \& Prevention, 59, 18-25. 